\title{
ASEAN financial market integration - a rainbow on the horizon?
}

\begin{abstract}
This paper reveals the degree of integration of financial markets in selected ASEAN economies. Few studies on this topic provide evidence that integration of the regionôs financial markets remains limited, despite the steady growth of intra-ASEAN trade (the share of intra-ASEAN trade to total ASEAN trade increased from $17 \%$ in 1990 to $24 \%$ in 2013). Over time, while the demand for financial services to support economic activities has led to financial system growth alongside economic development, the financial services appear to have less integration. We applied correlation and cointegration analyses to study financial integration over two periods (before and after the Asian financial crisis of three countries, namely Malaysia, Singapore and Thailand and three non-ASEAN countries, namely Hong Kong, Japan and the USA). Pairwise correlation of money-market rates appear to have increased from 8 (pre-crisis) to 15 (post-crisis) significantly. The multivariate co-integration test suggests the presence of at least two cointegrating equations (pre-crisis and post-crisis) in the money and stock markets of the ASEAN region.
\end{abstract}

Keyword: ASEAN-3; Share prices; Cointegration; Causality; Unit root testing; Transmission mechanism 